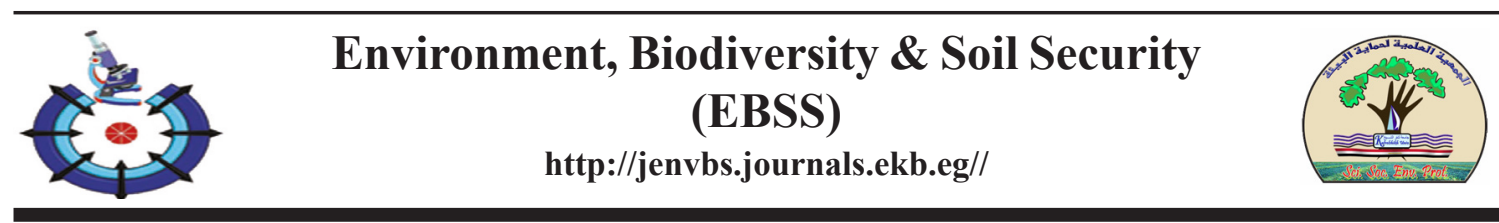

\title{
Monitoring Environmental Pathways of Trace Elements in the Northern East Area of Egypt
}

Mohamed A. Bassouny* and Mohamed H.H. Abbas ${ }^{\sharp}$

Soils and Water Department, Faculty of Agriculture, Benha University, Egypt

\begin{abstract}
$\mathbf{N}^{1}$ ILE Delta aquifer is one of the largest aquifers worldwide that receives the agrochemical leachates from the surrounding environments. To assess the status of some trace-elements (As, $\mathrm{Co}, \mathrm{Cd}, \mathrm{Pb}, \mathrm{Cu}$ and $\mathrm{Ni}$ ) in the North-East area of Egypt, well-water samples beside of surface, subsurface and deep-soil-samples were collected from 17 different locations to represent three environmental-pathways: the first one signifies areas relatively nearby Damiettabranch, while the third pathway stands for the arable lands nearby Ismaellia-canal. The second pathway is in-between these two pathways. Furthermore, a reference soil (irrigated with freshNile-water) was sampled for data comparison. These samples were estimated for their total and AB-DTPA-extractable contents of the aforementioned trace elements (TEs). Results revealed that AB-DTPA-extractable-TEs were in dynamic equilibrium with the corresponding soluble contents in irrigation water. Likewise, AB-DTPA-extractable-TEs significantly correlated with their corresponding total contents in soil. Concentrations of TEs in surface-soil-layer were higher than the corresponding ones in the subsurface and deep-soil-layers. The calculated values of contamination factor indicated moderate to very high levels of soil contamination with TEs. According to the principal component analysis, total and AB-DTPA-extractable-TEs in soil were affected by only one-principal-component, recording $86.13 \%$ of the data variance. This indicates that these contaminants originated probably from the same source. Moreover, multivariate-analyses revealed that total TEs significantly and positively correlated with soil hydraulic conductivity and bulk density, while negatively correlated with exchangeable sodium percentage, clay and organic matter contents. These results indicate that the groundwater flow is the potential source that enriched soils with TEs. Accordingly, any reductions in effluents of fresh Nile water, which is in hydraulic continuity with the groundwater in the studied area, can increase the severity of soil pollution with TEs in the studied area.
\end{abstract}

Keywords: The Nile Delta aquifer, Soil contamination, Trace elements, Contamination factor, Principal component analysis, Environmental pathways, Groundwater .

\section{Introduction}

Water scarcity and quality are the main challenges of sustainable agriculture worldwide (Reints et al., 2020). These two prospective problems are going to be further exacerbated in the future (Xu and $\mathrm{Li}, 2020)$. In Egypt, water crisis represents a potential threat (AbdAllah et al., 2019; Farid et al., 2020b and Rafaat et al., 2020) that affects negatively the sustainability of crop production in many of its arable lands (Darwesh, 2018; El-
Ramady et al., 2019; El-Ghannam et al., 2019; AbuZeid, 2020 and Zohry \& Ouda, 2020). This situation is thought to become more crucial upon the filling and operation of the Grand Ethiopian Renaissance Dam (Abdelazim etal., 2020 and Ouda \& Zohry, 2020). Thus, managing the available water resources in Egypt other than The Nile water (e.g. the groundwater) may bea valuable option to sustain land use in agriculture (Masoud, 2020). A positive point to note is that the Egyptian Nile Delta aquifer still represents,

*Corresponding emails: Mohamed.bassuony@fagr.bu.edu.eg

\#Mohamed.abbas@fagr.bu.edu.eg

Received 04/05/2020; Accepted 10/06/2020

DOI: 10.21608 /jenvbs.2020.29403.1094

C2020 National Information and Documentation Center (NIDOC) 
up-to-now,one of the largest aquifers worldwide (Sherif etal., 2012). This renewable resource is directly recharged by the Nile water (Negm et al., 2018) and can therefore, be a vital resource in many public activities (El Tahlawi et al., 2008). This aquiferis used for irrigating about 1.26 million ha (Sherif etal., 2012) with an annual recharge of approximately $6.70 \times 10^{6} \mathrm{~m}^{3} /$ year (Mikhailova, 2001). However, a proper management of this water resource is recommended because of its incapability to regenerate itself successfully while decreasing water allocations to Egypt by upstream countries (Stanley and Warne, 1998).

The Nile Delta aquifer is in direct contact with the Mediterranean Sea from the north and the Suez Canal from the east (Negm et al., 2018) with a slope of approximately $4 \mathrm{~m} / \mathrm{km}$, which is about 40 folds higher than the slope of the land surface (Said, 1993). Farmers, in such an area, depend mainly on natural drainage systems to get rid of excess water (Abd El Ghany et al., 2019) while soil-leachates reach groundwater carrying considerable amounts of agrochemical (Taha et al., 2004 and Sherif etal., 2012). These agrochemicals are thought to have negative ecological impacts (Abbas and Meharg, 2008; Eid et al. 2019 and Mohamed et al., 2019). Many of the extensively used agrochemicals contain trace elements (TEs) as impurities e.g., inorganic (Abdelhafez et al., 2012) and organic fertilizers (Elshony et al., 2019). These contaminants do not undergo biodegradation; and; therefore, persist in soils for years (Abdellatif et al., 2020); hence, possess potential long-term health hazards (Abdelhafez et al., 2015; Abbas and Bassouny, 2018; Mohamed et al., 2018 and ElShazly et al., 2019 a, b). Several studies have emphasized the presence of groundwater hydraulic continuity within the Nile Delta aquifer (Zeidan, 2017; Negm et al., 2018) and some others demonstrated that many of the soil locations overlying this aquifer are polluted with trace elements (Elewa, 2010). Consequently, an integrated approach, considering both soil contamination with TEs and hydraulic continuity is needed to bring up further details on the conditions of accumulation and redistribution of trace elements in such an area. This goal hasn't been pursued so far.

The current study evaluates the status of some trace elements (As, $\mathrm{Co} \mathrm{Cd}, \mathrm{Pb}, \mathrm{Cu}$ and $\mathrm{Ni}$ ) in groundwater of the north-east part of Nile Delta aquifer (17 different locations, 3 replicates each) whose area is estimated by $14,000 \mathrm{~km}^{2}$ according to Eltarabily and Negm (2017). It is thought that the soluble contents of the abovementioned trace elements are correlated significantly and positively with each other, indicating the presence of hydraulic continuity among the studied locations (First hypothesis). Distribution of these trace elements (total and AB-DTPA extractable contents) were also determined in the surface and the deeper soil layers collected from the areas nearby water sampling locations, taking into account 3 soil pathways: the first and second pathways extend from south to north-east (referring to the areas relatively nearby Damietta branch and wastewater drains, respectively) while the third pathway extends from the west part of the investigated area to the east part (referring to the arable lands nearby Ismaellia canal). If soil contaminants transfer and re-distribute long distances through the continuity of groundwater aquifer according to Farid et al. (2020a) and Bassouny et al. (2020), then these contaminants might move from the highlands located at the south part of the Nile Delta aquifer to the low lands located at the north-east/east part of the Nile Delta (Second hypothesis). We also assume that AB-DTPA extractable contents of trace elements are correlated significantly with the corresponding ones in groundwater and this probably indicates that the groundwater is the main source of soil contaminants, particularly TEs. These contaminants accumulated within the different soil layers and; therefore, ABDTPA extractable contents of trace elements are correlated significantly with their total contents in soil (Third hypothesis). Soil physical and chemical characteristics (e.g. $\mathrm{pH}, \mathrm{EC}$, hydraulic conductivity and the clay content) might have further significance impacts on accumulation and redistribution of these contaminants in soil (Fourth hypothesis) and therefore, the effects of these factors were also a matter of concern. Results of this study might have positive impacts on the management protocols that the government should follow to stop, or at least reduce, further trace elements contamination in such an area while sustaining land use in agriculture.

\section{Materials and Methods}

\section{Characterization of study area}

The study area is located in the North East area of the Nile Delta (Egypt) as shown in Fig.1. It is estimated by approximately $8,900 \mathrm{~km}^{2}$. Farmers of this area often use groundwater for irrigating their crops while using inefficient natural drains 
to get rid of excess water. It seems that the farmers therein depend on drainage water for irrigating their lands (Abd El Ghany et al., 2019). Accordingly, these soils suffer from contaminated high water table (Essam et al., 2020). The mean temperature in the investigated area is $22{ }^{\circ} \mathrm{C}$ and the total annual rainfall (mainly in winter) is approximately 56.0 mm (Hamman and Mohamed, 2018).

\section{Soil and water sampling}

To explore levels of soil contamination with trace elements in this area, surface $(0-30 \mathrm{~cm})$, subsurface $(30-60 \mathrm{~cm})$ and deep $(60-120 \mathrm{~cm})$ soil samples were collected from 17 different locations (3 replicates each). These locations represent three different pathways where soils of the first and second pathways use the groundwater as a main source of crop irrigation (referring to L1 to L12) while, soils of the third pathway represent the areas nearby Ismailia channel which is considered one of the tributaries of the River Nile (L1;L13;L14;L15;L16 and L17, see Fig 1); however, its water is severely contaminated with trace elements due to its nearness to Belbais drain as reported by El-Rawy et al. (2019). Samples of well waters were also collected from locations nearby the sites of soil sampling. Furthermore, a reference soil (irrigated with the Nile fresh water) was sampled for data comparison.

\section{Soil and water analyses}

Collected soil samples were air dried, crushed to pass through a $2 \mathrm{~mm}$ sieve then the samples of surface soil layers were analyzed for their chemical and physical characteristics according to the procedures presented by Sparks et al. (1996) and Klute (1986), respectively. Physicochemical characteristics of the investigated soil samples are presented in Table 1.The available indices of the investigated six trace elements (As, Co, Cd, $\mathrm{Pb}, \mathrm{Cu}$ and $\mathrm{Ni}$ ) were extracted from the different layers of the sampled soils by AB-DTPA according to the procedures recommended by Soltanpour (1985) and Shaheen et al. (2014). Other corresponding soil portions were digested by aquaregia $\left(\mathrm{HNO}_{3}\right.$ and $\left.\mathrm{HCl}\right)$ to estimate their total contents of trace elements. Afterwards, total and available concentrations of TEs were determined in soil extracts by Inductively Coupled Plasma Optical Emission (ICP-OES Perkin Elmer Optima 5300, USA) (Limits of

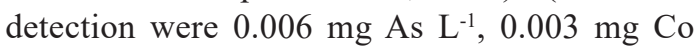
$\mathrm{L}^{-1}, 0.002 \mathrm{mg} \mathrm{Cd} \mathrm{L}^{-1}, 0.007 \mathrm{mg} \mathrm{Pb} \mathrm{L}^{-1}, 0.006 \mathrm{mg}$ $\mathrm{Cu} \mathrm{L}^{-1}$ and $0.005 \mathrm{mg} \mathrm{Ni} \mathrm{L}^{-1}$ ).

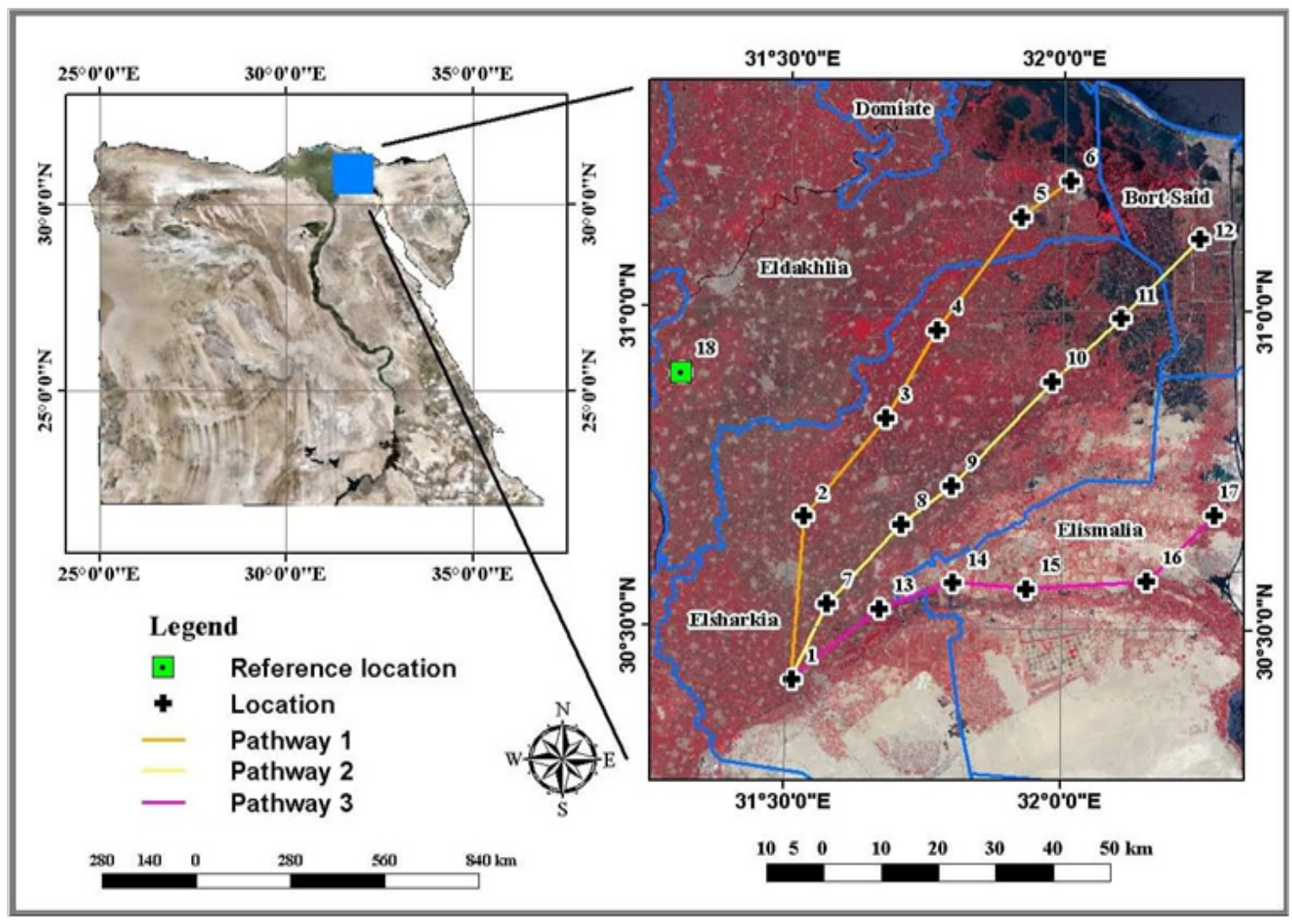

Fig. 1. Location map of the studied area 


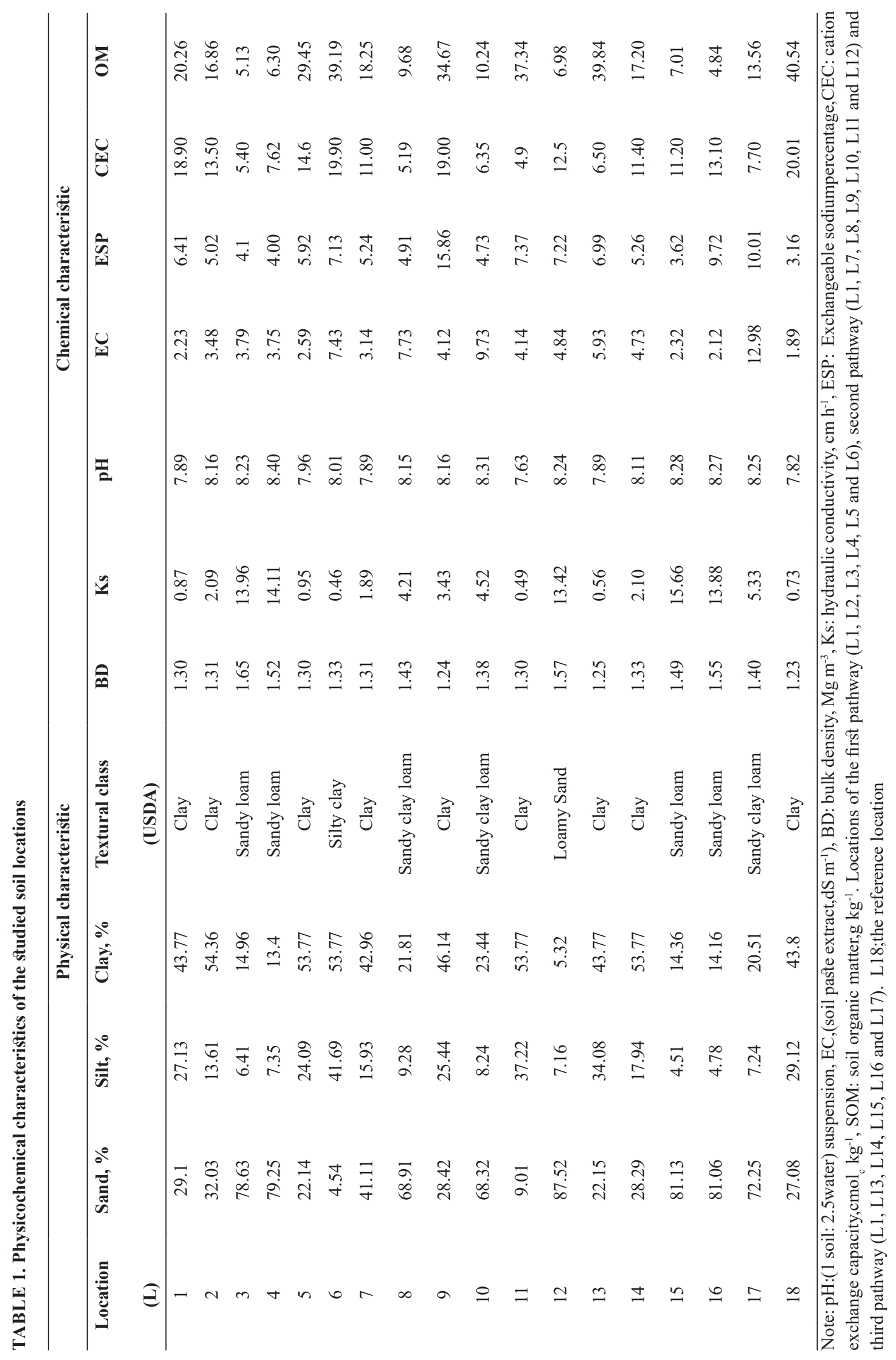

Env. Biodiv. Soil Security Vol. 4 (2020) 
Soluble contents of TEs were measured in water samples by Inductively Coupled Plasma Optical Emission. Chemical characteristics of water samples were conducted according to Nollet and De Gelder (2014).

\section{Quality assurance}

All chemicals and reagents were of analytical grade (purchased from Sigma/Merck/Fluka). Glasswares were rinsed in $10 \% \mathrm{HNO}_{3}$ overnight prior to their use; then washed thoroughly with deionized water. Blanks and spikes were set up in triplicates to test each of samples cross contamination and accuracy. The recovery data of the spike samples were $90.1 \%$ for $\mathrm{Cd}, 92.4 \%$ for As, $91.7 \%$ for $\mathrm{Co}, 93.2 \%$ for $\mathrm{Ni}, 91.3 \%$ for $\mathrm{Pb}$ and $90.3 \%$ for $\mathrm{Cu}$.

\section{Data analyses}

Data were statistically analyzed using PASW Statistics software 18. Contamination factor (CF) was then calculated as a ratio between the content of each trace element in soil relative to its corresponding background content (in the reference soil).

Contamination Factor $(C F)=$ (Concentration of an element in study samples)/(Corresponding $(1)$ ( concentration of this element in the background soil

The calculated values were then compared with the levels previously classified by Hakanson
(1980) as follows; $\mathrm{CF}<1$ low; $1 \leq \mathrm{CF} \leq 3$ moderate $3 \leq \mathrm{CF} \leq 6$ considerable and $\mathrm{CF} \leq 6$ as high contamination. The background levels of trace elements were determined in the reference soil as follows: $0.585 \mathrm{mg} \mathrm{Cd} \mathrm{kg}{ }^{-1}, 3.69 \mathrm{mg} \mathrm{As} \mathrm{kg}{ }^{-1}, 2.69 \mathrm{mg} \mathrm{Co}$ $\mathrm{kg}^{-1}, 12.31 \mathrm{mg} \mathrm{Ni} \mathrm{kg}{ }^{-1}, 11.65 \mathrm{mg} \mathrm{Pb} \mathrm{kg}{ }^{-1}, 12.63$ $\mathrm{mg} \mathrm{Cu} \mathrm{kg}{ }^{-1}$.

\section{Results and Discussion}

Groundwater as a potential source of soil contamination with trace elements

Water samples seemed to be highly contaminated with $\mathrm{As}, \mathrm{Co}$ and $\mathrm{Ni}$ as their concentrations exceeded the permissible levels recommended by WHO/FAO (2013) (Table 2). Likewise, $\mathrm{Cd}$ content in many of these waters exceeded the permissible level. On the other hand, all the studied locations exhibited low concentrations of $\mathrm{Pb}$ and $\mathrm{Cu}$ which were below the permissible levels (except for location 15 which recorded high concentrations of $\mathrm{Cu}$ beyond the permissible level).

A correlation study was then conducted to reveal that the concentrations of these trace elements were significantly correlated with each other (Table 3). This probably indicates the presence of groundwater hydraulic continuity among the studied locations. Accordingly, we accept the first hypothesis.

TABLE 2. Chemical characteristics of the groundwater samples collected from the studied locations.

\begin{tabular}{|c|c|c|c|c|c|c|c|c|c|}
\hline \multirow{2}{*}{ Location } & \multirow{2}{*}{ pH } & \multirow{2}{*}{$\underset{d S}{E C} \mathbf{m}^{-1}$} & \multirow{2}{*}{ SAR } & \multicolumn{6}{|c|}{ Concentrations, $\mathrm{mg} \mathrm{L}^{-1}$} \\
\hline & & & & As & Co & Cd & $\mathbf{P b}$ & $\mathbf{C u}$ & $\mathbf{N i}$ \\
\hline 1 & 8.450 & 2.080 & 4.210 & 0.660 & 0.240 & 0.023 & 0.520 & 0.141 & 0.230 \\
\hline 2 & 8.666 & 2.700 & 6.124 & 0.698 & 0.201 & 0.008 & 0.444 & 0.149 & 0.291 \\
\hline 3 & 8.520 & 2.680 & 4.390 & 0.740 & 0.150 & 0.020 & 0.440 & 0.130 & 0.260 \\
\hline 4 & 8.700 & 2.650 & 7.870 & 0.760 & 0.230 & 0.015 & 0.380 & 0.170 & 0.240 \\
\hline 5 & 8.682 & 2.740 & 6.324 & 0.700 & 0.190 & 0.008 & 0.446 & 0.141 & 0.242 \\
\hline 6 & 8.530 & 2.210 & 7.390 & 0.870 & 0.180 & 0.007 & 0.480 & 0.120 & 0.280 \\
\hline 7 & 8.648 & 2.720 & 6.173 & 0.699 & 0.206 & 0.008 & 0.448 & 0.151 & 0.330 \\
\hline 8 & 8.132 & 2.490 & 6.099 & 0.734 & 0.236 & 0.020 & 0.544 & 0.184 & 0.340 \\
\hline 9 & 7.820 & 2.700 & 7.890 & 0.830 & 0.260 & 0.023 & 0.420 & 0.190 & 0.250 \\
\hline 10 & 7.924 & 2.390 & 6.059 & 0.829 & 0.288 & 0.023 & 0.461 & 0.194 & 0.410 \\
\hline 11 & 8.014 & 2.665 & 6.646 & 0.840 & 0.241 & 0.019 & 0.540 & 0.204 & 0.360 \\
\hline 12 & 7.690 & 2.760 & 7.680 & 0.820 & 0.350 & 0.022 & 0.610 & 0.160 & 0.290 \\
\hline 13 & 8.689 & 2.575 & 6.562 & 0.698 & 0.193 & 0.008 & 0.4424 & 0.138 & 0.308 \\
\hline 14 & 8.586 & 2.635 & 6.177 & 0.769 & 0.254 & 0.015 & 0.504 & 0.151 & 0.374 \\
\hline 15 & 8.760 & 2.810 & 8.120 & 0.750 & 0.320 & 0.032 & 0.510 & 0.220 & 0.340 \\
\hline 16 & 8.459 & 2.766 & 7.169 & 0.837 & 0.335 & 0.029 & 0.607 & 0.171 & 0.339 \\
\hline 17 & 8.770 & 2.330 & 7.540 & 0.790 & 0.250 & 0.059 & 0.570 & 0.181 & 0.410 \\
\hline 18 (Nile water, background) & 7.350 & 1.760 & 3.840 & $\mathbf{0 . 5 4 7}$ & 0.135 & 0.004 & 0.278 & 0.105 & 0.195 \\
\hline Ref* & & & & 0.100 & 0.05 & 0.010 & 5.000 & 0.200 & 0.200 \\
\hline
\end{tabular}

* Note: Permissible levels of trace elements in water were set according to the guidelines of WHO/FAO (2013).

Bold values exceeded the permissible levels 


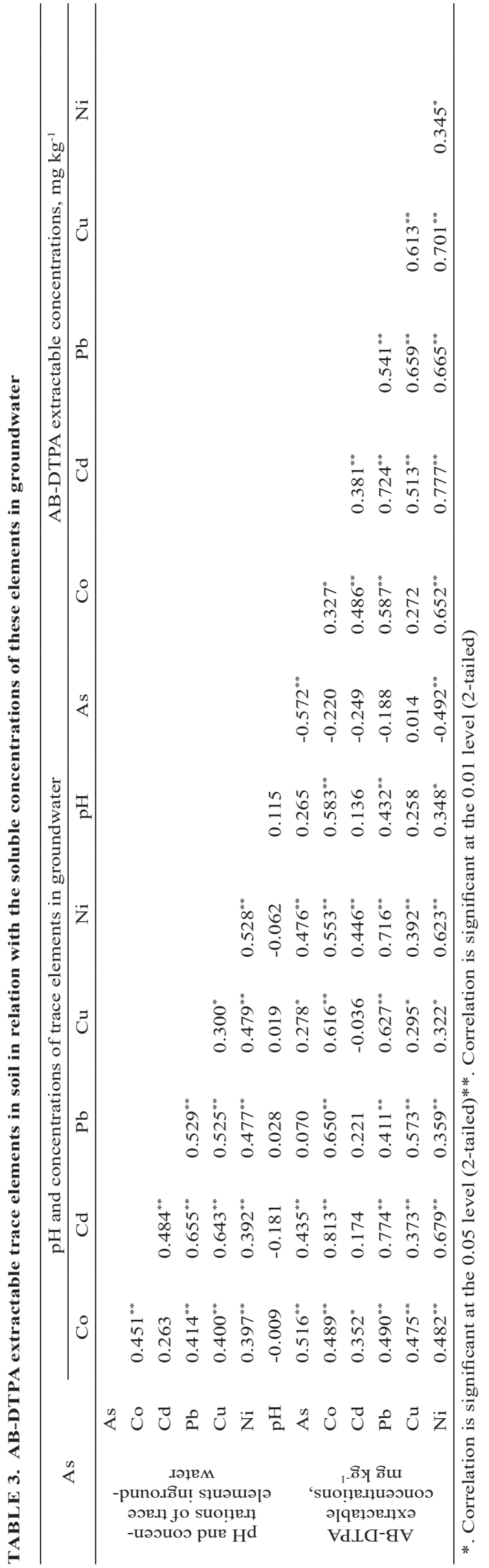

Such contaminated waters probably pollute the arable lands upon their use for irrigation. To investigate the mechanisms responsible for trace element accumulation in soil, total and AB-DTPAextractable contents of the studied trace elements were determined in surface, subsurface and deep soil layers sampled from locations nearby the sites of water sampling.

Total and AB-DTPA-extractable contents of trace elements in soil

Soils were sampled from 17 different locations to represent three pathways, differing in slope of groundwater in contact with either the Mediterranean Sea or the Suez Canal. The first pathway extends from the south-west part of the Nile Delta to the north east-area. This pathway is relatively the nearest one to Damietta branch. Consequently, soils, throughout this pathway, receive the effluents of the wastewater from the nearby drains on one hand, while receive the fresh Nile water loads from Damietta branch on the other hand. The third pathway extends from west to east. The second pathway is in-between these two pathways.

The potential $1^{\text {st }}$ pathway of trace element accumulation in the north-east area of The Nile Delta

Concentrations of the studied trace elements increased significantly in the surface top soil $(0-30 \mathrm{~cm})$ from locations L1 towards L3 (Fig $2)$; thereafter, these concentrations decreased noticeably. According to The European Union Soil Quality Guidelines (assessed at soil $\mathrm{pH}>7$ ), the permissible levels of trace elements in soils are $1.5 \mathrm{mg} \mathrm{Cd} \mathrm{kg}^{-1}, 100 \mathrm{mg} \mathrm{Pb} \mathrm{kg}{ }^{-1}, 70 \mathrm{mg} \mathrm{Ni}$ $\mathrm{kg}^{-1}$ and $\mathrm{mg} 100 \mathrm{Cu} \mathrm{kg}{ }^{-1}$ (Gawlik and Bidoglio (2006). In case of As and Co, the allowable levels are $20 \mathrm{mg} \mathrm{As} \mathrm{kg}^{-1}$ and $50 \mathrm{mg} \mathrm{Co} \mathrm{kg}{ }^{-1}$ (European Commission on Environment, 2002). Results obtained herein indicate that concentrations of the studied trace elements (except $\mathrm{Cd}$ ) did not exceed the permissible levels throughout the soils of this pathway. Such concentrations were relatively higher in the surface soil layers than the corresponding ones detected in the subsequent soil layers; especially $\mathrm{Co}$ and $\mathrm{Ni}$. The decline of trace element concentrations with soil depth was also reported by each of Kluge et al. (2018) and Abouzaid and Bassouny (2020). AB-DTPA extractable concentrations were also detected at relatively high concentrations in the surface soil layer $(0-30 \mathrm{~cm})$ while decreased significantly in the subsequent soil layers (i.e. sub-surface (30-60 $\mathrm{cm})$ and deep (60-120 cm) ones). 


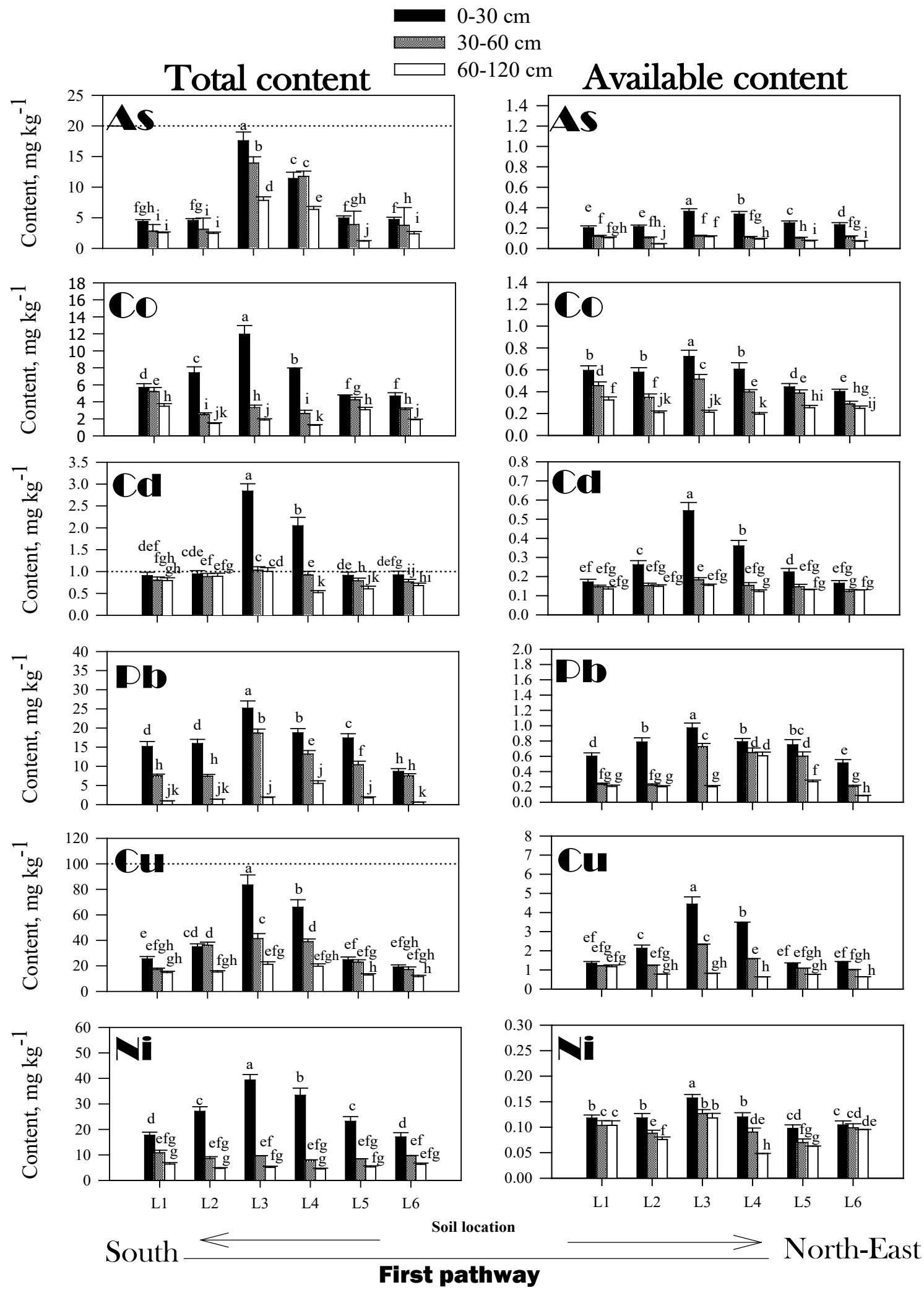

Fig. 2. Total and AB- DTPA extractable (available) contents of trace elements in soils of the first pathway. The dotted line indicates the maximum permissiblelevelsof TEs introduced by European Commission on Environment (2002) and The European Union Soil Quality Guidelines (2006). Similar letters indicate no significant variations among treatments 
The potential $2^{\text {nd }}$ pathway of trace element accumulation in the north-east area of The Nile Delta

Figure 3 reveals that total and AB-DTPA extractable contents of trace elements increased notably within the surface soil layer $(0-30 \mathrm{~cm})$ while decreased significantly in the subsequent layers $(30-60 \mathrm{~cm}$ and $60-120 \mathrm{~cm})$. In spite of that, there were significant higher concentrations of the investigated trace elements in the sub-surface soil layer i.e. 30-60 cm than the deepest one. These results agree with the findings of Abuzaid and Jahin (2019) which probably highlighted the significance of mobility and downward migration of TEs from the top soil. Trace element concentrations also increased significantly from the south part of the investigated area towards the north-east part. In this concern, the highest values of trace elements were detected at locations L11 (for As), L12 (for Co, Cu and $\mathrm{Pb}$ ), L10 (for Cd) and L9 (for Ni). According to The European Union Soil Quality Guidelines mentioned by Gawlik and Bidoglio (2006), these levels exceeded the maximum permissible ones (assessed at soil $\mathrm{pH}>7$ ). Likewise, the levels of As and Co also exceeded the allowable levels (20

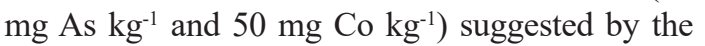
European Commission on Environment (2002).

It is worthy to mention that concentrations of trace elements in soils located on the first pathway were relatively lower than the corresponding ones detected in soils of the second pathway. This probably occurred because the soils of the first pathway were relatively nearer to the fresh Nile water resource of Damietta branch; accordingly, relatively high flushing of these contaminants occurred from soils to the Mediterranean Sea.

The potential $3^{\text {nd }}$ pathway of trace element accumulation in the north-east area of The Nile Delta

Figure 4 reveals that total and AB-DTPA extractable contents of the investigated trace elements increased significantly in the top soil (0$30 \mathrm{~cm}$ ) from the highlands (west area of The Nile Delta) towards the east (except for AB-DTPA-Cd). The highest concentrations of $\mathrm{As}, \mathrm{Co}$ and $\mathrm{Cu}$ were recorded at location No. "L15"; whereas, the highest concentrations of $\mathrm{Cd}, \mathrm{Pb}$ and $\mathrm{Ni}$ were detected at location No. "L14". These concentrations (especially $\mathrm{Pb}$ ) were, at the same time, significantly higher than the corresponding ones detected in the subsequent soil layers i.e. $30-60 \mathrm{~cm}$ and $60-120 \mathrm{~cm}$. This is probably because $\mathrm{Pb}$ accumulated at higher concentrations in the surface soil layers (Dotaniya et al., 2020) mainly in the form of lead phosphate
(Gao et al., 2020) due to extensive fertilization with P-fertilizers (Valipour et al., 2016). Moreover, this area is also near Ismailia-El-Zagazig highway.Thus, aerosol depositions might also enrich soils with $\mathrm{Pb}$ (Hashim et al., 2017) and Cu (El-Khatib et al.,2020) and the later element deposits in soils with relatively high mobile fractions (Zhou et al., 2020).

Level of soil contamination with trace elements

Levels of soil contamination with trace elements as exhibited by the contamination factor (Fig. 5 and 6), ranged widely from moderate to very high. In this concern, locations from numbers 15 to 17 were mildly contaminated with $\mathrm{As}, \mathrm{Co}, \mathrm{Cd}$ and $\mathrm{Pb}$. Likewise; locations from numbers 8 to 12 were mildly contaminated with $\mathrm{As}, \mathrm{Co}, \mathrm{Pb}, \mathrm{Cu}$ and $\mathrm{Ni}$. It seems that soil contamination with these trace elements increased notably from the south-west part of The Nile Delta towards the east.

Based on the results of total and AB-DTPA extractable trace elements in different soil location identifying the three environmental pathways, we can deduce that these contaminants might move from the highlands located at the south part of the Nile Delta aquifer to the low lands located at the north-east/east part of the Nile Delta and; therefore, we accept the Second hypothesis.

Table 4 presents the estimated areas $\left(\mathrm{km}^{2}\right)$ for each category of soil contamination with TEs. It seems that the majority of the studied locations suffer from considerable to high levels of soil contaminants. Accordingly, soil contamination with trace elements represents a major threat that should be considered while managing the arable lands in such an area.

\section{The principal component analysis (PCA)}

A principal component analysis (PCA) was then conducted with Varimax rotation while considering the total and AB-DTPA extractable concentrations of the investigated TEs in soil. This type of data analyses "reduces the dimensionality while preserving most of the variation in the data set" (Ringnér, 2008). According to the calculated high values of "KaiserMeyer-Olkin MSA" (MSA=0.611) in addition to the significant relations recorded on Bartless test of sphericity $(P<0.001)$, it can be deduced that satisfactory inter-correlations existed among the studied factors. Results presented in Table 5 indicate that only one component (Eigen value $>1$ ) described the retention data of trace elements in the studied area recording $86.13 \%$ of the variance in the data; and, therefore, accumulation of the studied trace elements in soil seemed to be originated from the same source of contamination. 


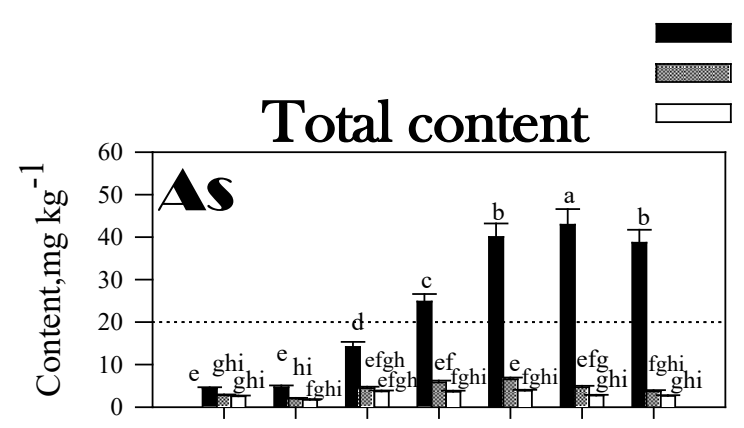

$0-30 \mathrm{~cm}$

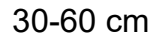

60-120 cm Available content
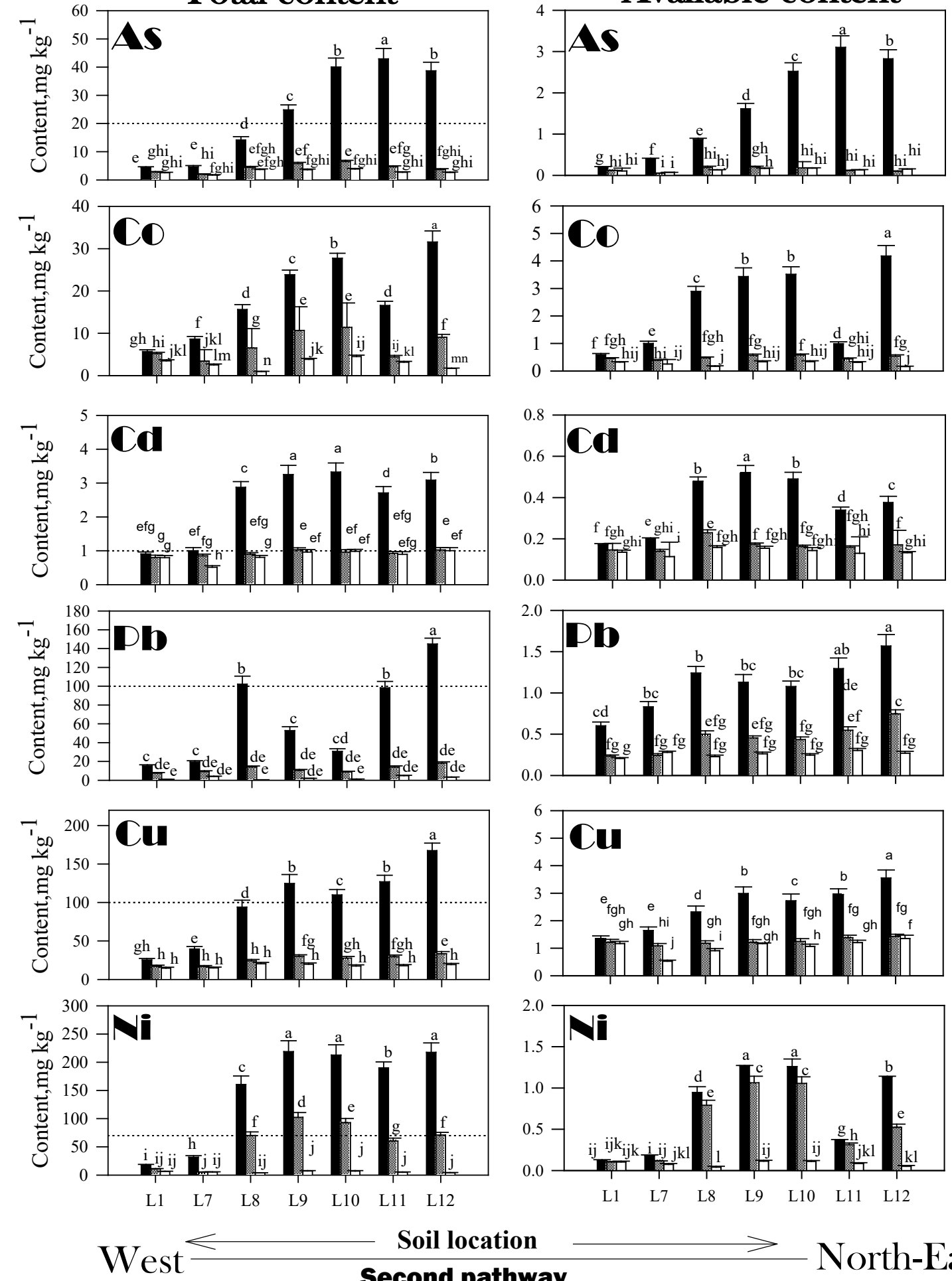

Soil location

\section{Second pathway}

Fig. 3. Total and AB- DTPA extractable (available) contents of trace elements in the investigated locations of the soils under study (second pathway). The dotted line indicates the maximum permissible levels of TEs introduced by The European Commission on Environment (2002) and The European Union Soil Quality Guidelines (2006). Similar letters indicate no significant variations among treatments 


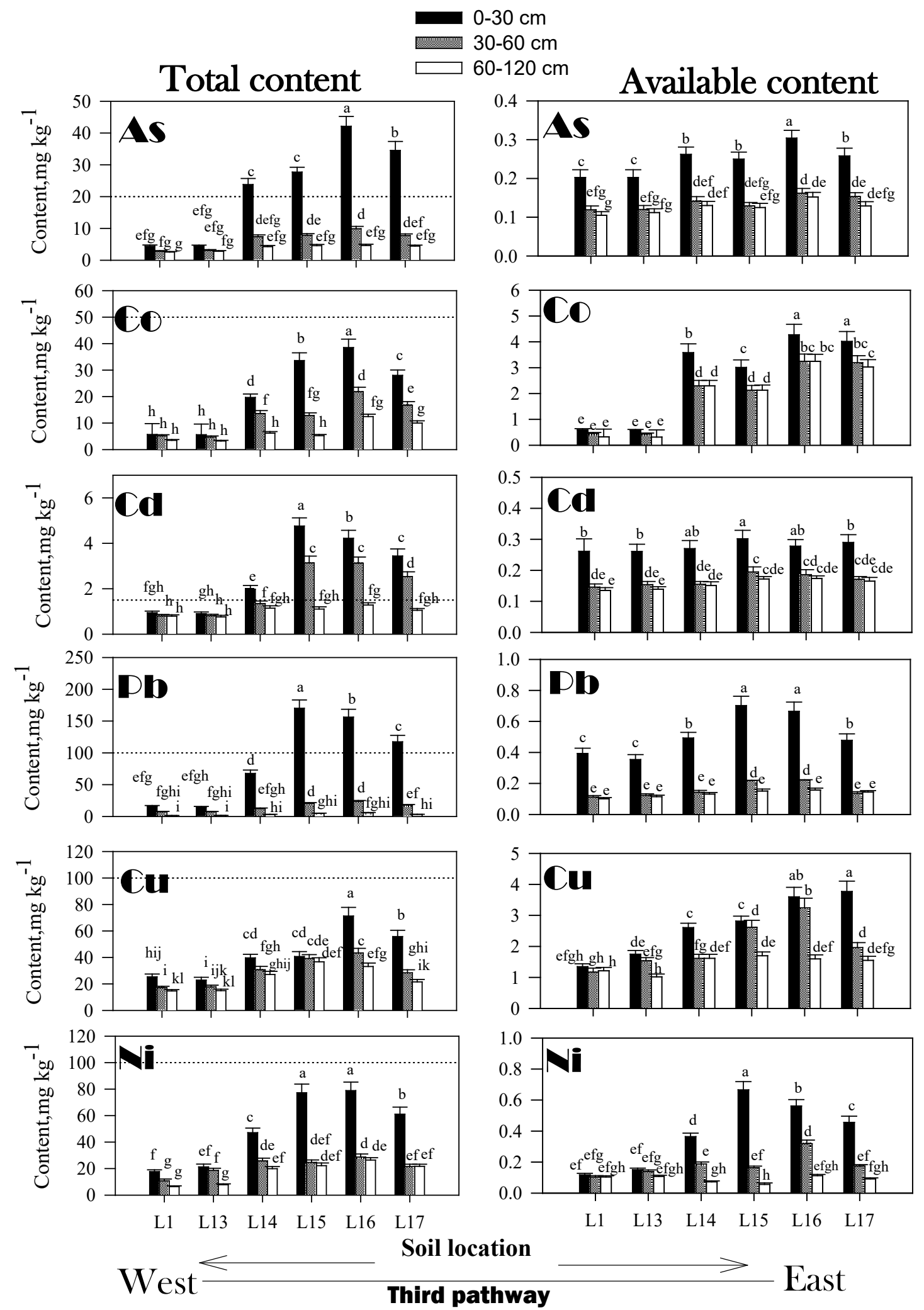

Fig. 4. Total and AB- DTPA extractable (available) contents of trace elements in the investigated locations of the soils under study (third pathway). The dotted line indicates the maximum permissible levels introduced by European Commission on Environment (2002) and The European Union Soil Quality Guidelines (2006). Similar letters indicate no significant variations among treatments 


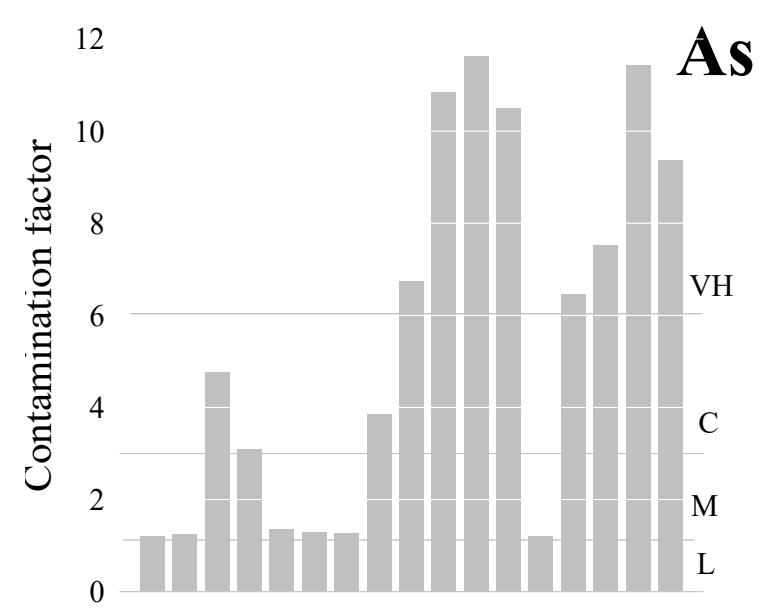

123345678991011121314151617
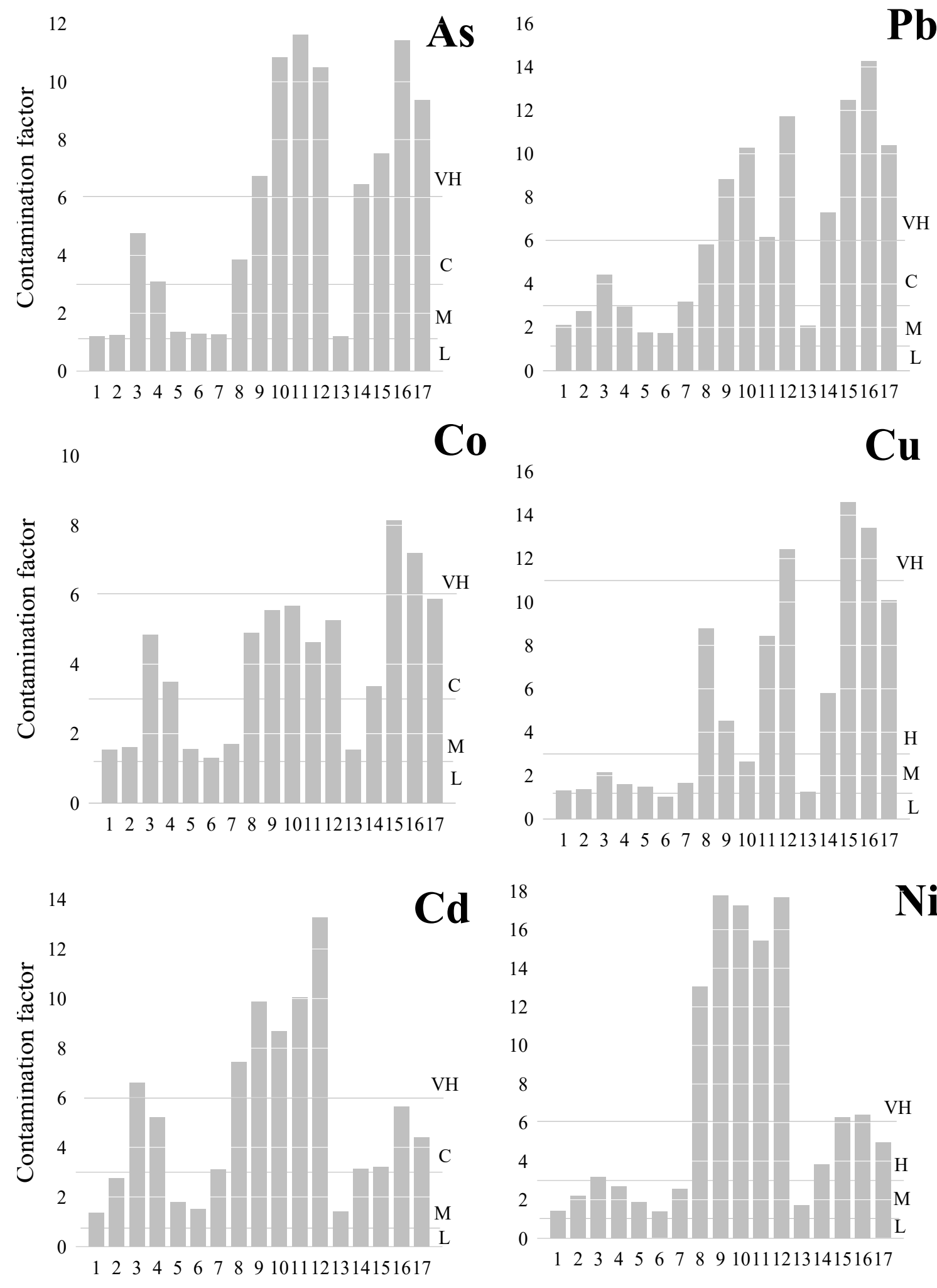

Soil location

Fig.5. Contamination factor (CF) of trace elements within the different investigated locations of the north-east area of the Nile Delta (note: L:low, M: moderate, C:considerable, VH: very high) 

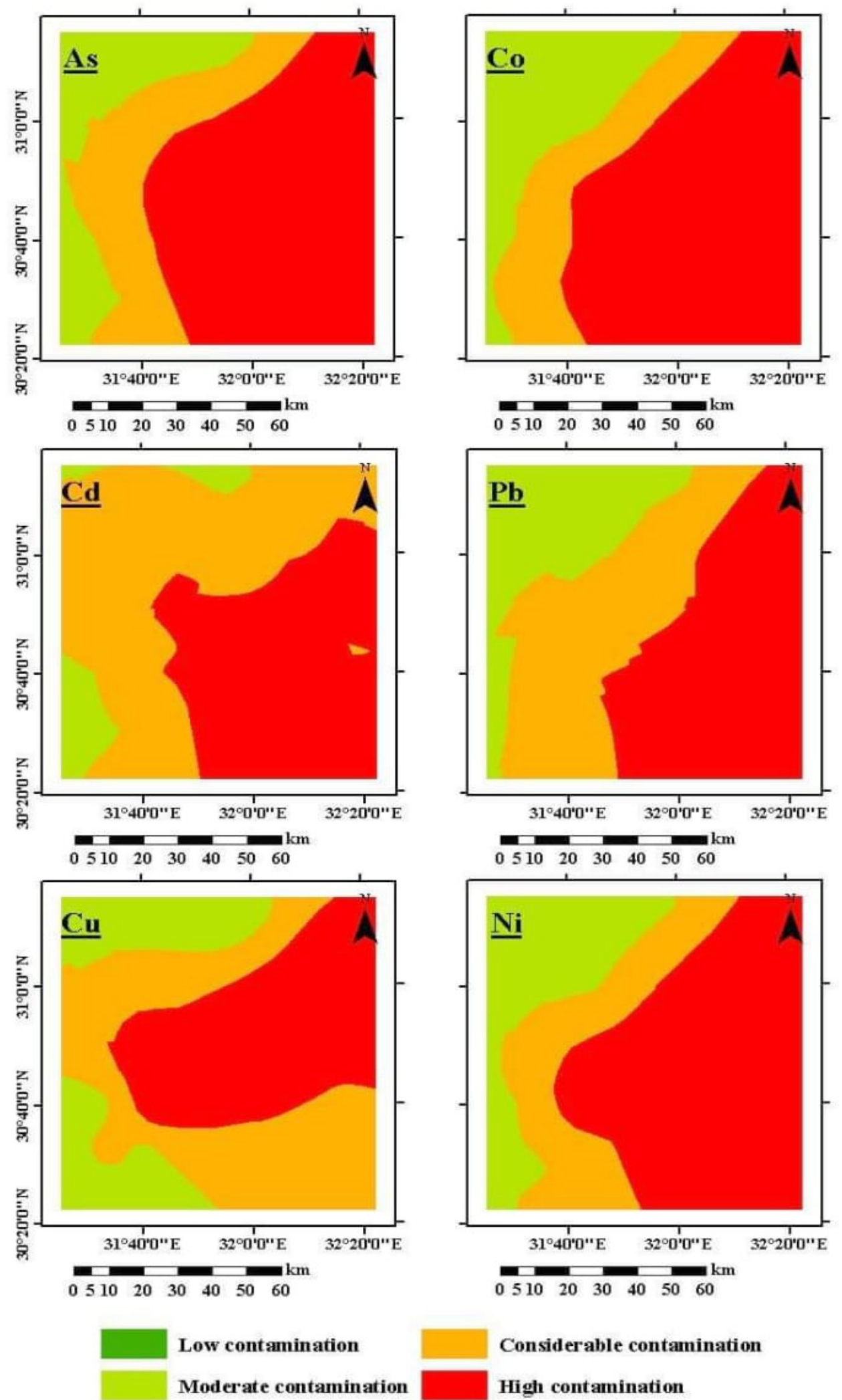

\section{Considerable contamination \\ High contamination}

Fig. 6. Spatial distribution of contaminants within the investigated locations of the north-east area of the Nile Delta (based on the calculations of contamination factor) 
TABLE 4. Areas $\left(\mathrm{km}^{2}\right)$ representing each category of soil contamination with TEs in the studied area.

\begin{tabular}{cccccccc}
\hline \multirow{2}{*}{ Contamination level } & \multicolumn{2}{c}{ Moderate } & \multicolumn{2}{c}{ Considerable } & \multicolumn{2}{c}{ High } & \multirow{2}{*}{ Total area } \\
\cline { 2 - 6 } & Area $\left(\mathbf{k m}^{2}\right)$ & $\mathbf{\%}$ & Area $\left(\mathbf{k m}^{2}\right)$ & $\mathbf{\%}$ & Area $\left(\mathbf{k m}^{2}\right)$ & $\mathbf{\%}$ & \\
\hline $\mathrm{Ni}$ & 1583.31 & 17.78 & 2154.74 & 24.20 & 5164.90 & 58.01 & 8902.95 \\
$\mathrm{Cu}$ & 1952.58 & 21.93 & 1751.23 & 19.67 & 5199.14 & 58.40 & 8902.95 \\
$\mathrm{~Pb}$ & 590.66 & 6.63 & 4442.61 & 49.90 & 3869.68 & 43.47 & 8902.95 \\
$\mathrm{Cd}$ & 1940.56 & 21.80 & 3121.01 & 35.06 & 3841.37 & 43.15 & 8902.95 \\
$\mathrm{Co}$ & 1907.83 & 21.43 & 3548.22 & 39.85 & 3446.90 & 38.72 & 8902.95 \\
$\mathrm{As}$ & 1955.32 & 21.96 & 2026.16 & 22.76 & 4921.47 & 55.28 & 8902.95 \\
\hline
\end{tabular}

TABLE 5. Principal component analysis (PCA) of trace elements in the soils of the area under study (north-east of Egypt).

\begin{tabular}{|c|c|c|c|c|c|c|}
\hline \multirow{2}{*}{$\begin{array}{c}\text { Trace } \\
\text { element } \\
\text { (TE) }\end{array}$} & \multirow{2}{*}{$\begin{array}{c}\text { Component } \\
\text { "one" }\end{array}$} & \multirow[b]{2}{*}{ Communalities } & \multirow[b]{2}{*}{ Component } & \multicolumn{3}{|c|}{ Initial Eigenvalues } \\
\hline & & & & Total & $\begin{array}{l}\% \text { of Vari- } \\
\text { ance }\end{array}$ & Cumulative \% \\
\hline As & 0.964 & 0.930 & 1 & 5.168 & 86.129 & 86.129 \\
\hline Co & 0.956 & 0.915 & 2 & 0.545 & 9.077 & 95.206 \\
\hline $\mathrm{Cd}$ & 0.955 & 0.913 & 3 & 0.111 & 1.857 & 97.063 \\
\hline $\mathrm{Cu}$ & 0.904 & 0.809 & 4 & 0.082 & 1.361 & 98.424 \\
\hline $\mathrm{Pb}$ & 0.899 & 0.817 & 5 & 0.063 & 1.048 & 99.471 \\
\hline $\mathrm{Ni}$ & 0.885 & 0.784 & 6 & 0.032 & 0.529 & 100.000 \\
\hline
\end{tabular}

To study factors responsible of trace element accumulation in the investigated area, two multiple correlations were conducted. The first one considered the relations between AB-DTPA extractable (available) contents of trace elements in soil and the corresponding soluble contents in groundwater that is used for irrigation. The second one estimated the relationship between both total and AB-DTPA extractable (available) contents of trace elements in soil in relation with soil physical and chemical characteristics.

AB-DTPA extractable (available) contents of trace elements in soil in relation with the soluble contents of these trace elements in wells (groundwater)

Concentrations of trace element in groundwater were significantly and positively correlated with the corresponding AB-DTPA extractable contents in soil (see Table 3). Moreover, ABDTPA extractable - As and Ni were significantly and negatively correlated with the $\mathrm{pH}$ values of groundwater. It seems that dynamic equilibrium probably existed between soluble concentrations of TEs in groundwater and the corresponding available contents in soil. This dynamic equilibrium was also noticed by Abdel-Aal et al. (2011). Accordingly, it can be deduced that these elements spread via groundwater over a wider area (Zeidan, 2017). However, some other factors may increase their retention in soil such as the $\mathrm{pH}$ of groundwater which probably increased the precipitation of As and Ni. The alkaline nature of these waters probably played significant roles in increasing As oxidation (Han et al., 2019) and precipitation (Zhang et al., 2020). Likewise, Nihydroxides can precipitate under such alkaline conditions (Musso et al., 2019). 


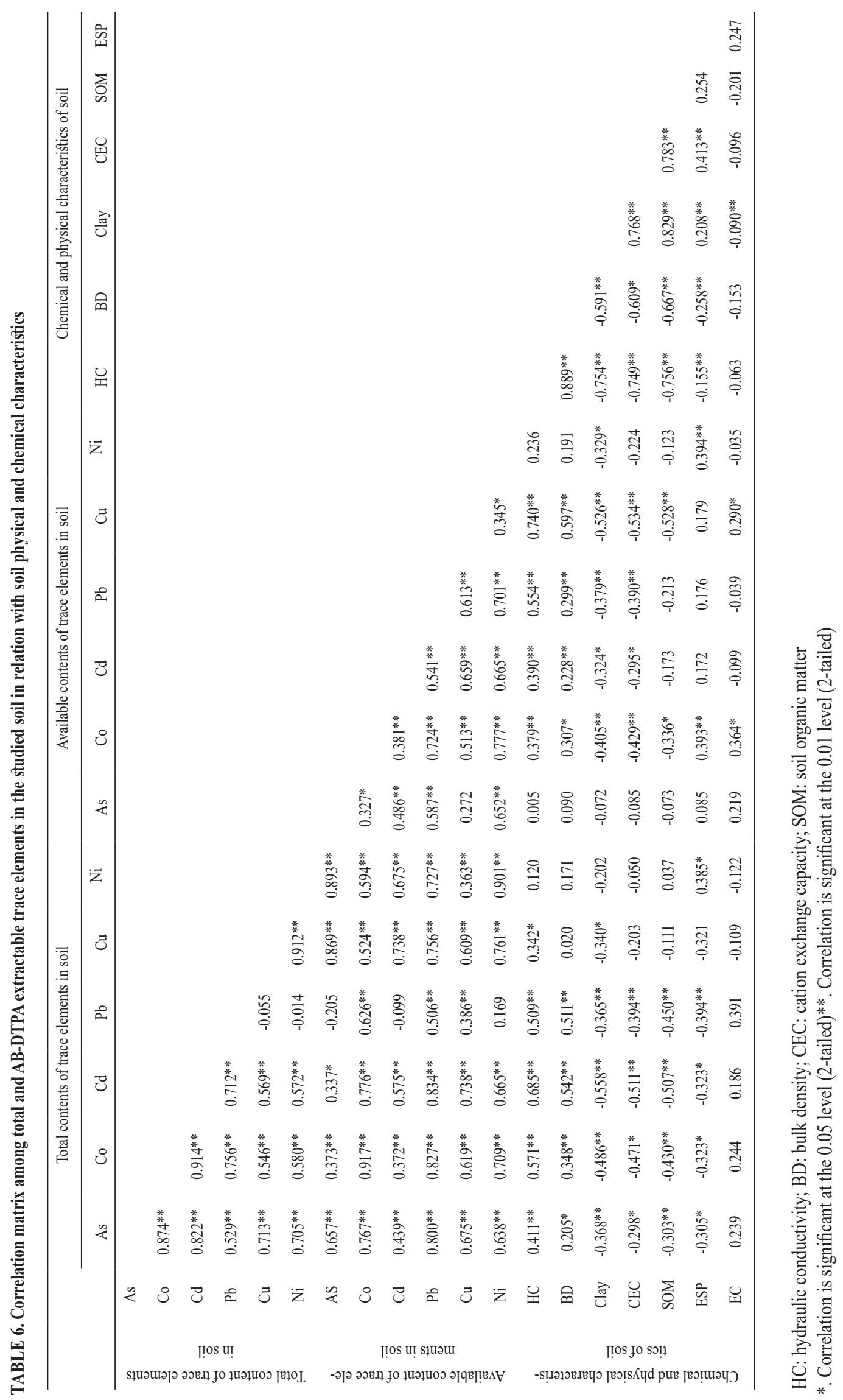

Env. Biodiv. Soil Security Vol. 4 (2020) 
Multivariate analyses among total and AB-DTPA extractable (available) contents of trace elements in soil in relation to soil physical and chemical characteristics

Table 2 indicates that available concentrations of the studied trace elements within different soil locations and depths significantly correlated with their corresponding total contents in soil. Probably, the alkaline $\mathrm{pH}$ range of the studied soils increased TEs precipitations and accumulations (Hale et al., 2012; Kluge et al., 2018; Abuzaid et al., 2019 and Dotaniya et al., 2020). As mentioned above, such available concentrations of TEs were significantly correlated with TEs contents in well waters. Thus, we accept the Third hypothesis. Likewise, the total contents of TEs correlated significantly with each other. This also confirms that the source of soil contamination with trace elements might be the same. It seems that soil physical and chemical characteristics played the major significant roles in controlling the accumulation of trace elements within the studied locations. In this concern, the highest positive significant correlations were recorded for soil hydraulic conductivity, then for soil bulk density. This might occur because of the diffusion of trace elements through the groundwater continuity within The Nile Delta aquifer. Farmers, growing plants thereon, use flooding irrigation method mainly to water their crops; consequently, they dug a lot of wells to fulfill their irrigation needs. On the other hand, hydraulic connection probably exists between the groundwater therein and the wastewaters of the nearby drains (Eissa et al., 2019); especially the discharges of Bahr El-Baqr drain (agricultural activities, domestic and industrial discharges) (Taha et al., 2004; Abde-Elaty et al., 2019) which is heavily polluted and anoxic (Khadr and Elshemy, 2017). Moreover, farmers of this area (especially Sharkia governorate) set irrigation networks by using drain water illegally (Mostafa et al., 2019). It seems that the regional groundwater flow and the surface flow regime are the potential sources of water in this area (Mikhailova, 2001) which significantly enriched soils with trace elements. Without seasonal flushing by floods, toxic levels of trace elements are more likely built up in the Delta plain (Stanley and Warne, 1998).

It is worthy to mention that clay particles effectively control the accumulation of trace elements in soil (Abbas and Bassouny, 2018). Also, soil organic matter decreased significantly the mobility of $\mathrm{Cu}$ in soil while increased the $\mathrm{Co}$ mobility (Lange et al., 2016 and 2017). However, the results obtained in Table 5 indicate that each of the clay content as well as soil organic matter recorded negative significant correlations with each of the total and AB-DTPA extractable contents of trace elements in soil. This might take place because both the clay and organic matter contents in soils probably formed layers of low filtration rates (Patle et al., 2019). Moreover, clay particles reserve $\mathrm{Na}$ ions in soil; which consequently increased clay dispersion (Ali et al., 2019), while decreased soil hydraulic conductivity (Arienzo et al., 2012).This is an important aspect for water and salts transportation (Klopp and Daigh, 2019). Thus, there is no wonder to find out that the total concentrations of trace elements significantly and negatively correlated with soil ESP (Table 2).

\section{Conclusion}

Soil contamination with trace elements represents an environmental problem in the north east region of The Nile Delta, Egypt. These contaminants existed mainly in the groundwater and found their way to the different soil layers through upraise of groundwater from areas of high water potential to areas of relatively lower ones (different soil layers). Loads of these contaminants were significantly correlated with each of soil hydraulic conductivity and bulk density. Although, clay and organic matter contents reserved some of these contaminants in soil (recording less significant correlations with each of AB-DTPA and total contents of trace elements in soil); however, these two factors might not be the main responsible ones for trace element accumulation in soil (both recorded negative correlations with total contents of TEs in soil). Probably, the metal ions of these elements underwent further oxidation and/or precipitation on the top soil layer $(0-30 \mathrm{~cm})$ under the arid conditions dominant therein; thus, accumulated at relatively high concentrations (exceeded sometimes the permissible levels). It is therefore thought that water flooding; although being a natural disaster; however, it is the optimum solution to reduce the levels of soil contaminants within the Nile Delta aquifer area. On the other hand, reductions in fresh Nile water effluents which are in hydraulic continuity with the groundwater in the studied area can consequently increase the severity of soil pollution with trace elements. It is recommended to introduce and manage safe bio-approaches to substitute the traditionally used agrochemicals for crop production in order to lessen further soil degradation therein due to trace elements contamination while sustaining land use in agriculture. 


\section{Acknowledgement}

Authors would like to thank Prof. Hassan H. Abbas (Soils and Water department, Faculty of Agriculture, Benha University), Dr Ahmed A.Abdelhafez (Soils and Water Department, Faculty of Agriculture, New Valley University)for their support and assistance while conducting this study

\section{References}

Abbas, M. and Meharg, A. (2008) Arsenate, arsenite and dimethyl arsinic acid (DMA) uptake and tolerance in maize (Zea mays L.). Plant Soil, 304 (1/2), 277-289. https://doi.org/10.1007/s11104$\underline{008-9549-9}$

Abbas, M.H.H. and Bassouny, M. (2018) Implications of long term irrigation with wastewater on the contents and retention kinetics of potentially toxic elements in Typic Torripsamment soils. Egypt $J$ Soil Sci. 58 (3), 337-357. https://doi.org/10.21608/ ejss.2018.4232.1183

AbdAllah, S., El-Ramady, H., El-Sherbeni, A., Anber, H., Keshk, E., Hamed, S. and Amine, H. (2019) Monitoring water quality of some canals in Delta region, Egypt. Env. Biodiv. Soil Security3, 73-95. https://doi.org/10.21608/jenvbs.2019.11428.1057

Abd El Ghany, S.H., Saleh, O.K. and Osman, M.A. (2019) Applying different abstraction pattern to achieve better water management, Alex Eng J. 58 (1), 181-187, https://doi.org/10.1016/j. aej.2018.01.008.

Abdel-Aal, M.S., Shaltout, A.A. and Mostafa, N.Y. (2011) Spectroscopic study of heavy metals at different depths in southeastern soil of Nile Delta, Egypt, Spectrosc Lett, 44 (3),186-193. https://doi. org/10.1080/00387010.2010.495153.

Abd-Elaty, I., Zelenakova, M., Straface, S., Vranayová, Z. and Abu-hashim, M. (2019) Integrated modelling for groundwater contamination from polluted streams using new protection process techniques. Water 11, 2321. https://doi.org/10.3390/w11112321

Abdelazim, N., Bekhit, H. and Allam, M.N. (2020) Operation of the grand Ethiopian Renaissance dam: Potential risks and mitigation measures. J. Water Manag. Model, 27, C469. https://doi.org/10.14796/ JWMM.C469.

Abdelhafez, A.A., Abbas, H.H., Abd-El-Aal, R.S., Kandil, N.F., Li, J. and Mahmoud, W. (2012) Environmental and health impacts of successive mineral fertilization in Egypt. Clean Soil Air Water, 40, 356-363. https://doi.org/10.1002/ clen.201100151.
Abdelhafez, A.A., Abbas, M.H.H. and Attia, T.M.S. (2015) Environmental monitoring of heavy-metals status and human health risk assessment in the soil of Sahl El-Hessania area, Egypt. Pol. J. Environ Stud. 24 (2), 459-467.

Abdellatif, M.M., Soliman, S.M.A., El-Sayed, N.H., Hassan, F. and Abdellatif, H. (2020) Iotacarrageenan based magnetic aerogels as an efficient adsorbent for heavy metals from aqueous solutions. J Porous Mater. 27, 277-284. https://doi. org/10.1007/s10934-019-00812-Z.

Abuzaid, A.A. and Jahin, H.S. (2019) Profile distribution and source identification of potentially toxic elements in North Nile Delta, Egypt. Soil Sediment Contam. 28 (6), 582-600, https://doi.org /10.1080/15320383.2019.163781.

Abuzaid, A.S. and Bassouny, M.A. (2020) Total and DTPA-extractable forms of potentially toxic metals in soils of rice fields, north Nile Delta of Egypt, Environ Technol Inno. 18, 100717, https://doi. org/10.1016/j.eti.2020.100717

Abuzaid, A.S., Bassouny, M.A., Jahin, H.S. and Abdelhafez, A.A. (2019) Stabilization of lead and copper in a contaminated Typic Torripsament soil using humic substances. Clean - Soil, Air, Water, 47, 1800309, https://doi.org/10.1002/ clen.201800309.

AbuZeid, K.M. (2020) Existing and Recommended Water Policies in Egypt. In: Zekri S. (Ed) Water Policies in MENA Countries. Global Issues in Water Policy, vol 23. Springer, Cham, pp 47-62, https://doi.org/10.1007/978-3-030-29274-4 3.

Ali, A., Biggs, A. J.W., Marchuk, A. and Bennett, J. Mc L. (2019) Effect of irrigation water $\mathrm{pH}$ on saturated hydraulic conductivity and electrokinetic properties of acidic, neutral, and alkaline soils. Soil Sci. Soc. Am. J. 83, 1672-1682, https://doi.org/10.2136/ sssaj2019.04.0123.

Arienzo, M., Christen, E.W., Jayawardane, N.S. and Quayle, W.C. (2012) The relative effects of sodium and potassium on soil hydraulic conductivity and implications for winery wastewater management, Geoderma, 173-174, 303-310, https://doi. org/10.1016/j.geoderma.2011.12.012.

Bassouny, M., Abbas, M. and Mohamed, I. (2020) Environmental risks associated with the leakage of untreated wastewater in industrial Areas. Egypt $J$ Soil Sci.60 (2), 109-120, https://doi.org/10.21608/ ejss.2019.18787.1319.

Darwesh, R. (2018) Water productivity for Egyptian clover as affected by different irrigation regimes 
and cultivation methods in the North Middle Nile Delta region. Env. Biodiv. Soil Security, 2 (2018), 193-203, https://doi.org/10.21608/ jenvbs.2019.6775.1043.

Dotaniya, M.L., Dotaniya, C.K., Solanki, P., Meena, V.D. andR.K. Doutaniya (2020) Lead Contamination and Its Dynamics in Soil-Plant System. In: Gupta D., Chatterjee S., Walther C. (Ed) Lead in Plants and the Environment. Radionuclides and Heavy Metals in the Environment. Springer, Cham, pp 83-98, https://doi.org/10.1007/978-3030-21638-2_5.

Eid, K.E., Abbas, M.H.H., Mekawi, E.M., ElNagar, M.M., Abdelhafez, A.A., Amin, B.A., Mohamed, I. and Ali, M.M. (2019) Arbuscular mycorrhiza and environmentally biochemicals enhance the nutritional status of Helianthus tuberosus and induce its resistance against Sclerotium rolfsii, Ecotox Environ Safe. 186,109783, https://doi. org/10.1016/j.ecoenv.2019.109783

Eissa, M., Ali, M., Zaghlool, E. and Stash, O.S. (2019) Hydrochemical and stable isotopes indicators for detecting sources of groundwater contamination close to Bahr El-Baqar drain, eastern Nile Delta, Egypt,Water Sci. 33 (1),54-64, https://doi.org/10.1 080/11104929.2019.1635346.

Elewa, H.H. (2010)Potentialities of Water Resources Pollution of the Nile River Delta, Egypt. The Open Hydrology Journal, 4, 1-13. http://dx.doi.org/10.21 74/1874378101004010001.

El-Ghannam, M., Abdel-Razek, M. and Abo ElSoud, H. (2019) Quality assessment of some water sources and soil under sea water intrusion conditions in north Nile Delta, Egypt. Env. Biodiv. Soil Security 3, 179-192, https://doi.org/10.21608/ jenvbs.2019.19036.1073.

ElShazly, A.A.A., Abbas, M.H.H., Farid, I.M., Rizk, M., Abdelhafez, A.A., Abbas, H.H., Soliman, S.M., Abdel Sabour, M.F. and Mohamed, I. (2019a) Depthprofile distribution of Cs and its toxicity for canola plants grown on arid rainfed soils as affected by increasing K-inputs. Ecotox Environ Safe. 183, 109529, https://doi.org/10.1016/j. ecoenv.2019.109529.

ElShazly, A.A.A., Abbas, M.H.H., Farid, I.M., Rizk, M., Mohamed, I., Abbas, H.H., Abdelhafez, A.A., Soliman, S.M. and Abdel Sabour, M.F. (2019b) Feasibility of using natural mineral ores for removing $\mathrm{Cs}$ and $\mathrm{Sr}$ from contaminated water. Ecotox Environ Safe. 175, 173-180, https://doi. org/10.1016/j.ecoenv.2019.03.044.

El Tahlawi, M. R., Farrag, A. A. andS. S. Ahmed,
(2008)Groundwater of Egypt: “an environmental overview”. Environ Geol. 55, 639-652. https://doi. org/10.1007/s00254-007-1014-1.

Eltarabily, M.G.A. and Negm, A.M. (2017) Groundwater Management for Sustainable Development East of the Nile Delta Aquifer. In: Negm A. (Ed.) Groundwater in the Nile Delta. The Handbook of Environmental Chemistry, vol 73. Springer, Cham, pp 687-708, https://doi. org/10.1007/698_2017_102.

El-Khatib, A.A., Barakat, N.A., Youssef, N.A. and Samir, N.A. (2020) Bioaccumulation of heavy metals air pollutants by urban trees. Int $J$ Phytoremediat, 22 (2), 210-222, https://doi.org/10 $.1080 / 15226514.2019 .1652883$.

El-Ramady, H., Abowaly, M., Elbehiry, F., Omara, A., Elsakhawy, T., Mohamed, S., Belal, A., Elbasiouny, H. and Abdalla, Z. (2019) Stressful environments and sustainable soil management: A case study of Kafr El-Sheikh, Egypt. Env. Biodiv. Soil Security, 3, 193-213, https://doi.org/10.21608/ jenvbs.2019.17750.1070.

El-Rawy, M., Fathi, H.andAbdalla, F. (2019) Integration of remote sensing data and in situ measurements to monitor the water quality of the Ismailia Canal, Nile Delta, Egypt. Environ Geochem Health. https://doi.org/10.1007/s10653019-00466-5.

Elshony, M., Farid, I., Alkamar, F., Abbas, M. and Abbas, H. (2019) Ameliorating a sandy soil using biochar and compost amendments and their implications as slow release fertilizers on plant growth. Egypt J Soil Sci. 59 (4), 305-322, https:// doi.org/10.21608/ejss.2019.12914.1276.

Essam, D., Ahmed, M., Abouelmagd, A. and Soliman, F. (2020) Monitoring temporal variations in groundwater levels in urban areas using ground penetrating radar.Sci Total Environ. 703,134986. https://doi.org/10.1016/j.scitotenv.2019.134986.

European Commission on Environment (2002) Heavy Metals in Wastes. Available on line:at: http://c. ymcdn.com/sites/www.productstewardship.us/ resource/resmgr/imported/Heavy $\% 20$ Metals $\% 20$ in\%20Waste.pdf (accessed on 22 January 2016).

Farid, I., Abbas, M., Bassouny, M., Gameel, A. and Abbas, H. (2020a) Indirect impacts of irrigation with low quality water on the environmental safety. Egypt J Soil Sci. 60 (1), 1-15. https://doi. org/10.21608/ejss.2019.15434.1294.

Farid, I., Hashem, A., Abd El-Aty, E., Abbas, M. and Ali, M. (2020b). Integrated approaches towards 
ameliorating a saline sodic soil and increasing the dry weight of barley plants grown thereon. Env. Biodiv. Soil Security, 4 (2020), 31-46. https://doi. org/10.21608/jenvbs.2020.12912.1086

Gao, H., Dai, W., Fang, K., Yi, X., Chen, N., Penttinen, P., Sha, Z. and Cao, L. (2020) Rice-duck coculture integrated different fertilizers reduce $\mathrm{P}$ losses and $\mathrm{Pb}$ accumulation in subtropical China, Chemosphere, 245,125571, https://doi. org/10.1016/j.chemosphere.2019.125571.

Gawlik, B.M. andG. Bidoglio(2006) Background values in European soils and sewage sludges. European Commission, Brussels. http://eusoils.jrc. ec.europa.eu/ESDB_Archive/eusoils_docs/other/ eur22265_3.pdf.

Hakanson, L. (1980) An ecological risk index for aquatic pollution control.a sedimentological approach, Water Res, 14 (8), 975-1001. https://doi. org/10.1016/0043-1354(80)90143-8.

Hale, B., Evans, L. and Lambert, R. (2012) Effects of cement or lime on $\mathrm{Cd}, \mathrm{Co}, \mathrm{Cu}, \mathrm{Ni}, \mathrm{Pb}, \mathrm{Sb}$ and Zn mobility in field-contaminated and aged soils. J. Hazard Mater.199-200, 119-127. https://doi. org/10.1016/j.jhazmat.2011.10.065

Hammam, A.A. and Mohamed, E.S. (2018) Mapping soil salinity in the East Nile Delta using several methodological approaches of salinity assessment, Egypt. J. Remote Sens. Space Sci., https://doi. org/10.1016/j.ejrs.2018.11.002.

Han, Y.-S., Park, J.-H., Kim, S.-J., Jeong, H.Y. and SungAhn, J. (2019) Redox transformation of soil minerals and arsenic in arsenic-contaminated soil under cycling redox conditions. J Hazard Mater 378, 120745. https://doi.org/10.1016/j. jhazmat.2019.120745.

Hashim, T.A., Abbas, H.H., Farid, I. M., El-Husseiny, O. H. M. and Abbas, M. H. H. (2017) Accumulation of some heavy metals in plants and soils adjacent to Cairo - Alexandria agricultural highway. Egypt. J. Soil Sci.57 (2), 215- 232. https://doi.org/10.21608/ ejss.2016.281.1047

Khadr, M. and Elshemy, M. (2017) Data-driven modeling for water quality prediction case study: The drains system associated with Manzala Lake, Egypt, Ain Shams Eng J. 8 (4),549-557, https://doi. org/10.1016/j.asej.2016.08.004.

Klopp, H.W. and Daigh, A.L.M.(2019) Measured saline and sodic solutions effects on soil saturated hydraulic conductivity, electrical conductivity and sodium adsorption ratio, Arid Land Res Manag, DOI: $\underline{10.1080 / 15324982.2019 .1672221}$
Kluge, B., Markert, A., Facklam, M., Sommer, H., Kaiser, M., Pallasch, M. and Wessolek, G. (2018) Metal accumulation and hydraulic performance of bioretention systems after long-term operation. $J$ Soils Sediments, 18, 431-441. https://doi. org/10.1007/s11368-016-1533-Z

Klute, A. (1986) Part 1. Physical and mineralogical methods.ASA-SS SA-Agronomy, Madison, Wisconsin USA.

Lange, B., Pourret, O., Meerts, P., Jitaru, P., Cancès, B., Grison, C. and Faucon, M.-P. (2016) Copper and cobalt mobility in soil and accumulation in a metallophyte as influenced by experimental manipulation of soil chemical factors, Chemosphere, 146, 75-84. https://doi. org/10.1016/j.chemosphere.2015.11.105

Lange, B., van der, Ent, A., Baker, A.J.M., Echevarria, G., Mahy, G., Malaisse, F., Meerts, P., Pourret, O., Verbruggen, N. and Faucon, M.-P. (2017) Copper and cobalt accumulation in plants: a critical assessment of the current state of knowledge. New Phytol, 213, 537-551. https://doi.org/10.1111/ nph.14175

Masoud, M. (2020) Groundwater Resources Management of the Shallow Groundwater Aquifer in the Desert Fringes of El Beheira Governorate, Egypt. Earth Syst Environ. 4, 147-165. https://doi. org/10.1007/s41748-020-00148-8

Mikhailova, M. (2001) Hydrological regime of the Nile Delta and dynamics of its coastline. Water Resour. 28 (5), 477-490. https://doi. org/10.1023/A:1012320920434

Mohamed, I., Ali, M., Ahmed, N., Abbas, M.H.H., Abdelsalam, M., Azab, A., Raleve, D. and Fang, C. (2018) Cow manure-loaded biochar changes $\mathrm{Cd}$ fractionation and phytotoxicity for wheat in a natural acidic contaminated soil. Ecotoxicol Environ Saf. 162, 348-353. https://doi.org/10.1016/j. ecoenv.2018.06.065

Mohamed, I., Eid, K.E., Abbas, M.H.H., Salem, A.A., Ahmed, N., Ali, M., Shah, G.M.and C. Fang (2019) Use of plant growth promoting Rhizobacteria (PGPR) and mycorrhizae to improve the growth and nutrient utilization of common bean in a soil infected with white rot fungi. Ecotoxicol Environ Safe. 171, 539-548. https://doi.org/https://doi. org/10.1016/j.ecoenv.2018.12.100

Mostafa, G., Fahmy, M., Ramadan, S. and Shalash, O. (2019) Evaluation of water shortage in east Nile Delta.Int J Civ Eng Technol. 10 (5), 170-180

Musso, T. B., Parolo, M. E. and Pettinari, G. (2019) pH, 
Ionic strength, and ion competition Effect on $\mathrm{Cu}$ (II) and Ni(II) sorption by a Na-bentonite used as liner material. Pol J Environ Stud. 28 (4), 2299-2309. https://doi.org/10.15244/pjoes/84922

Negm, A.M., Sakr S., Abd-Elaty I. and Abd-Elhamid, H.F. (2018) An Overview of Groundwater Resources in Nile Delta Aquifer. In: Negm A. (Ed) Groundwater in the Nile Delta. The Handbook of Environmental Chemistry, 73. 3-44. https://doi. org/10.1007/698 $2017 \quad 193$

Nollet, L. and De Gelder, L. (2014) Handbook of Water Analysis. Boca Raton: CRC Press, https://doi. org/10.1201/b15314.

Ouda S. and A.EH. Zohry (2020) Water Scarcity Leads to Food Insecurity. In: Deficit Irrigation. Springer, Cham, pp 1-13. https://doi.org/10.1007/978-3-030$\underline{35586-9} 1$

Patle, G.T., Sikar, T.T., Rawat, K.S. and Singh, S.K. (2019) Estimation of infiltration rate from soil properties using regression model for cultivated land, Geology, Ecology, and Landscapes, 3 (1), 113. $10.1080 / 24749508.2018 .1481633$

Rafaat, R., Osman, H., Georgy, M. and Elsaid, M. (2020) Preferred risk allocation in Egypt's water sector PPPs.Int. J. Constr. Manag, DOI: $\underline{10.1080 / 15623599.2019 .1703087}$

Ringnér, M. (2008) What is principal component analysis?. Nat Biotechnol. 26, 303-304. https://doi. org/10.1038/nbt0308-303

Said, R. (1993) The Nile River: Geology, Hydrology, and Utilization. Pergamon, New York, USA.

Shaheen, S.M., Rinklebe, J., Frohne, T., White, J.R. and DeLaune, R.D. (2014) Biogeochemical factors governing cobalt, nickel, selenium, and vanadium dynamics in periodically flooded Egyptian North Nile Delta rice soils. Soil Sci Soc Am J, 78: 10651078. https://doi.org/10.2136/sssaj2013.10.0441

Sherif, M., Sefelnasr, A. and Javadi, A. (2012) Incorporating the concept of equivalent freshwater head in successive horizontal simulations of seawater intrusion in the Nile Delta aquifer, Egypt. J Hydrol. 464-465, 186-198. https://doi. org/10.1016/j.jhydrol.2012.07.007

Soltanpour, P.N. (1985) Use of ammonium bicarbonate DTPA soil test to evaluate elemental availability and toxicity. Commun Soil Sci Plant Anal. 16, 323338. https://doi.org/10.1080/00103628509367607

Sparks, D.L., Page, A.L., Helmke, P.A., Loeppert, R.H., Soltanpour, P.N., Tabatabai, M.A., Johnston, C.T. and Sumner, M.E. (1996) Methods of Soil
Analysis Part 3-Chemical Methods, 5.3, SSSA Book Series, Madison, WI.

Reints, J., Dinar, A. and Crowley, D. (2020) Dealing with water scarcity and salinity: Adoption of water efficient technologies and management practices by California avocado growers. Sustainability, 12, 3555. https://doi.org/10.3390/su12093555

Stanley, D. and Warne, A. (1998) Nile Delta in its destruction phase. J Coast Res, 14 (3), 795-825.

Taha, A., El-Mahmoudi, A. S. and El-Haddad, I. M. (2004) Pollution sources and related environmental impacts in the new communities Southeast Nile Delta, Egypt. Emirates Journal for Engineering Research, 9 (1), 35-49

Valipour, M., Shahbazi, K. and A. Khanmirzaei(2016) Chemical immobilization of lead, cadmium, copper, and nickel in contaminated soils by phosphate amendments. Clean Soil Air Water, 44, 572-578. https://doi.org/10.1002/clen.201300827

WHO/FAO (2013) Guidelines for the Safe Use of Wastewater and food stuff: volume 2: No1 14.Wastewater Use in Agriculture, World Health Organization, Geneva.

$\mathrm{Xu}, \mathrm{M}$. and Li, C. (2020) The Concepts of Virtual Water and Water Footprint. In: Application of the Water Footprint: Water Stress Analysis and Allocation. Springer, Singapore, pp 9-16. https:// doi.org/10.1007/978-981-15-0234-7_2

Zeidan, B.A. (2017) Groundwater Degradation and Remediation in the Nile Delta Aquifer. In: Negm A. (Ed.) The Nile Delta. The Handbook of Environmental Chemistry, 55. 159-232. https://doi. org/10.1007/698_2016_128

Zhang, X., Tian, J., Han, H., Sun, W., Hu, Y., Wang, T.Y.L., Yang, Y., Cao, X.and Tang, H. (2020) Arsenic removal from arsenic-containing copper and cobalt slag using alkaline leaching technology and $\mathrm{MgNH}_{4} \mathrm{AsO}_{4}$ precipitation, Sep Purif Technol, 238,116422. https://doi.org/10.1016/j. seppur.2019.116422

Zhou, J., Du, B., Liu, H., Cui, H., Zhang, W., Fan, X., Cui, J. and Zhou, J. (2020) The bioavailability and contribution of the newly deposited heavy metals (copper and lead) from atmosphere to rice (Oryza sativa L.). J Hazard Mater. 384, 121285. https:// doi.org/10.1016/j.jhazmat.2019.121285.

Zohry, A.EH. and Ouda, S. (2020) Egypt Faces Water Deficiency, and Food Insufficiency. In: Deficit Irrigation. Springer, Cham, pp 29-58. https://doi. org/10.1007/978-3-030-35586-9 3 